УДК 657.1.011.56

DOI: https://doi.org/10.26642/jen-2021-2(96)-61-69

С.Ф. Легенчук, д.е.н., проф.

Т.П. Назаренко, к.е.н., доц.

І.М. Царук, к.е.н., доц.

Державний університет «Житомирська політехніка»

\title{
Принципи захисту даних у системі обліку: управлінські аспекти
}

\begin{abstract}
Обтрунтовано необхідність проведення досліджень у напрямі підвищення рівня безпеки бухгалтерських даних в умовах удосконалення системи обліку на основі технологічних інновацій. Описано загальний процес перетворення даних на інформацію в інформаційних системах. Проаналізовано загальну модель функиіонування бухгалтерських інформаційних систем. Обтрунтовано сутність поняття бухгалтерських даних у вузькому й широкому розумінні та поняття облікової інформації. Розглянуто поняття безпеки інформаційної системи обліку. Проаналізовано підходи вчених до виокремлення принципів захисту даних. Обтрунтовано сутність окремих принцииів захисту бухгалтерських даних (иілісність, конфіденційність, доступність). Визначено систему правил, якої необхідно дотримуватись працівникам бухгалтерської служби для забезпечення иілісності бухгалтерських даних на підприємстві. Визначено причини порушення конфіденційності бухгалтерських даних. Визначено роль принципів безпеки даних у підвищенні якості облікової інформації.
\end{abstract}

Ключові слова: комп'ютерна система обліку, захист бухгалтерських даних, інформаційна безпека підприємства, принщиипи безпеки даних.

Актуальність теми. На сучасному етапі розвитку бухгалтерського обліку як засобу інформаційного забезпечення системи управління його ефективне функціонування значно мірою пов'язане із належним захистом бухгалтерських даних, порушення якого може призвести до зменшення ефективності управлінських рішень, що приймаються менеджерами на основі облікової інформації. Це може бути пов'язано як 3 порушенням безпеки або конфіденційності бухгалтерських даних, що стосуються діяльності підприємства, так і даних про зовнішніх стейкхолдерів, які взаємодіють 3 цим підприємством. Актуальність захисту бухгалтерських даних на підприємствах підтверджують дослідження представників компанії «Сisco», згідно 3 якими у 2016-2017 роках інформація про операційну та фінансову діяльність підприємства займали перше (37 \%) та друге (29 \%) місця серед всіх зламів їхньої системи безпеки, які впливають на виробничу діяльність [2, с. 51]. Наведене вище зумовлює необхідність дослідження проблемних питань побудови систем захисту бухгалтерських даних як в умовах застосування сучасних технологічних інновацій, так і безпосередньо в умовах функціонування традиційних комп'ютерних систем обліку. Для цього насамперед необхідною є розробка теоретичних засад для побудови таких систем, зокрема, обгрунтування принципів захисту даних та визначення можливості їх використання в процесі проєктування й удосконалення систем обліку.

Аналіз останніх досліджень та публікацій, на які спираються автори. Питанням безпеки інформаційних систем бухгалтерського обліку присвячені дослідження К.П. Боримської, І.Л. Грабчук, О.О. Григоревської, А.П. Дикого, В.В. Євдокимова, Й.Женга, Н.Я. Корнієнка, Г.І. Ляхович, В.В. Муравського, В.О. Осмятченка, I.І. Світлишина, М.І. Скрипник та іншими.

Мета статті - 3 огляду на сутність бухгалтерських даних, проаналізувати можливості застосування принципів їх безпеки в процесі функціонування комп’ютерних систем обліку.

Викладення основного матеріалу. Бухгалтерський облік $\epsilon$ інформаційною системою, яка забезпечує збір, обробку, перетворення, збереження та представлення облікової інформації різним групам заінтересованих користувачів. Обліковий процес на підприємстві є сукупністю облікових процедур (документування, інвентаризація, рахунки, подвійний запис, оцінка, калькулювання, баланс, звітність), в результаті здійснення яких інформаційна система отримує дані про особливості функціонування суб’єкта бухгалтерського обліку (підприємства, групи підприємств), забезпечуючи їх збереження, подальшу обробку, захист і надання менеджменту підприємства та іншим різним групам користувачів у вигляді бухгалтерської звітності (фінансової, управлінської, податкової тощо), на основі якої вони можуть приймати управлінські рішення.

Зокрема, менеджменту підприємства потрібна оперативна, тактична та стратегічна інформація для більш ефективного управління підприємством; статистичні органи потребують інформації для формування державної статистичної звітності; інвесторам та інституційним інвесторам необхідна інформація для здійснення інвестиційних вкладень у найбільш ефективні підприємства; позикодавцям необхідна інформація для встановлення вартості позикових коштів; податковими органами облікова інформація використовується для встановлення правильності здійснення облікових платежів; 
профспілкові організації використовують облікову інформацію для відстоювання прав працівників підприємства; громадським організаціям потрібна облікова інформація для визначення ролі цього підприємства у функціонуванні громади й суспільства в цілому. 3 інституційної точки зору бухгалтерський облік є окремим соціально-економічним інститутом, політичною та інституційною практикою, а також засобом забезпечення ефективності ринку капіталу за допомогою ефективного перерозподілу капіталу між галузями економіки. За таким підходом бухгалтерський облік не лише відображає в інформаційному вимірі економічну реальність підприємства, а також здійснює конструювання соціальної реальності, яка існує паралельно й одночасно з навколишнім фізичним світом, що є предметом системи бухгалтерського обліку.

Застосовувана на підприємствах система бухгалтерського обліку, що також реалізована із використання інформаційних технологій, заснована на концепції подвійного запису. Для уніфікації порядку відображення господарських операцій використовується нормативно закріплений план рахунків як нормативно визначена класифікація об’єктів бухгалтерського обліку (активи, зобов'язання, капітал, доходи та витрати), застосування якої дозволяє формувати стандартизовану інформацію у фінансовій, статистичній та податковій звітності про стан і результати діяльності підприємства. Управлінська звітність формується на кожному підприємстві на власний розсуд і нормативно не регламентується, оскільки є внутрішнім інструментом формування інформації та в окремих випадках належить до комерційної таємниці.

Якщо раніше (на початку 2000-х років) на малих та середніх підприємствах через нестачу фінансових ресурсів і техніко-технологічні проблеми досить часто використовувалася ручна форма обліку, без застосування інформаційних систем і технологій, що вимагала ручної обробки бухгалтерських документів, заповнення облікових регістрів та формування звітності, то в умовах сьогодення на переважній більшості підприємств і бюджетних установ ці процеси є автоматизованими, що вимагає меншої кількості бухгалтерів для щоденного обслуговування й сприяє економії витрат. На всіх великих підприємствах, які мають складну організаційну структуру та значну кількість бізнес-процесів, і як наслідок, достатньо великі обсяги облікових робіт, а також для управління якими необхідна оперативна, достовірна та релевантна інформація, впроваджені спеціалізовані управлінські інформаційні системи ERP-класу, що містять окремі облікові (фінансові) модулі та забезпечують виконання необхідних обліково-аналітичних функцій.

В умовах сьогодення відбувається остаточна трансформація підходів до ведення бухгалтерського обліку на підприємствах, що характеризується відходом від ручної форми ведення обліку й паперового документообігу та переходом до мережево-комп'ютеризованої форми обліку й електронного документообігу. Сучасні облікові системи підприємств, дозволяючи подолати недоліки ручної форми обліку (економія витрат на утримання облікових працівників, зменшення обсягів робочого простору, швидкість обробки та передачі інформації, покращена точність, форми візуалізації тощо), одночасно, через специфіку свого функціонування (мережеве середовище, машинна обробка та збереження даних тощо), створюють нові види загроз безпеці бухгалтерських даних.

Незважаючи на те, що облікова система підприємства має значні обмеження (надання інформації користувачам у фінансовому вимірнику, чітко визначена кількість об'єктів бухгалтерського спостереження та форм представлення облікової інформації тощо), через що не вся інформація про стан та результати діяльності підприємства може бути надана користувачам, в цілому ії функціонування спрямоване на зменшення інформаційної невизначеності стосовно господарської діяльності підприємства, внаслідок чого облікова система забезпечує виконання інформаційної, сигнальної, контрольної й комунікаційної функцій.

Загальні особливості функціонування бухгалтерських інформаційних систем можна більш детально зрозуміти як процес застосування інформаційних технологій до систем бухгалтерського обліку 3 урахуванням специфіки функціонування систем фінансового обліку, управлінського обліку, аудиту та оподаткування. В умовах формування інформаційного суспільства, що характеризується значним рівнем комп’ютеризації господарської діяльності підприємств, можна констатувати, що розвиток інформаційних систем і технологій суттєво впливає на практику бухгалтерського обліку, порядок його організації на підприємстві та в цілому на розвиток бухгалтерського обліку як окремої системи наукових знань. В останні роки це стало особливо відчутним в умовах активного впровадження технологічних інновацій у систему бухгалтерського обліку (Artificial Intelligence, Big Data, Internet of Things, Cloud Computing, Data Analytics, Visualization Tools тощо) [3, с. 36], що поступово впливають на трансформацію традиційних облікових процедур - збір, обробку, узагальнення та передачу облікової інформації користувачам.

В основі дослідження бухгалтерських інформаційних систем досить часто використовуються положення системного підходу, згідно з яким бухгалтерський облік слід розглядати як окрему систему, що має входи і виходи, внутрішню структуру (сукупність внутрішніх процесів), взаємодіє 3 іншими системами підприємства (рис. 1). 


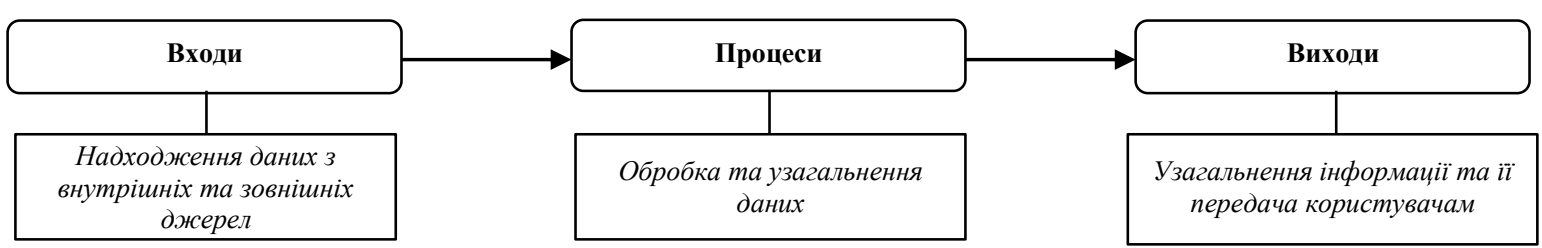

Рис. 1. Загальний процес перетворення даних на інформаџію в інформаџійних системах

На рисунку 1 наведено основні компоненти інформаційної системи, що забезпечують процес перетворення даних на інформацію, яка використовується суб'єктами управління для підтримки процесів, планування, організації, мотивації, координації, оцінки бізнес-процесів та контролю господарської діяльності підприємства або їі окремих бізнес-процесів. Цей процес є триступеневим, на першій стадії якого необроблені дані надходять до системи, на другій стадії відбувається сортування й обробка таких даних, їх поступове перетворення на інформацію, а на третьому етапі забезпечується остаточне змістовне наповнення (перетворення) інформації та ії передача різним групам користувачів.

Відповідно до з розглянутого вище процесу (рис. 1) загальну модель функціонування бухгалтерських інформаційних систем можна представити таким чином (рис. 2).

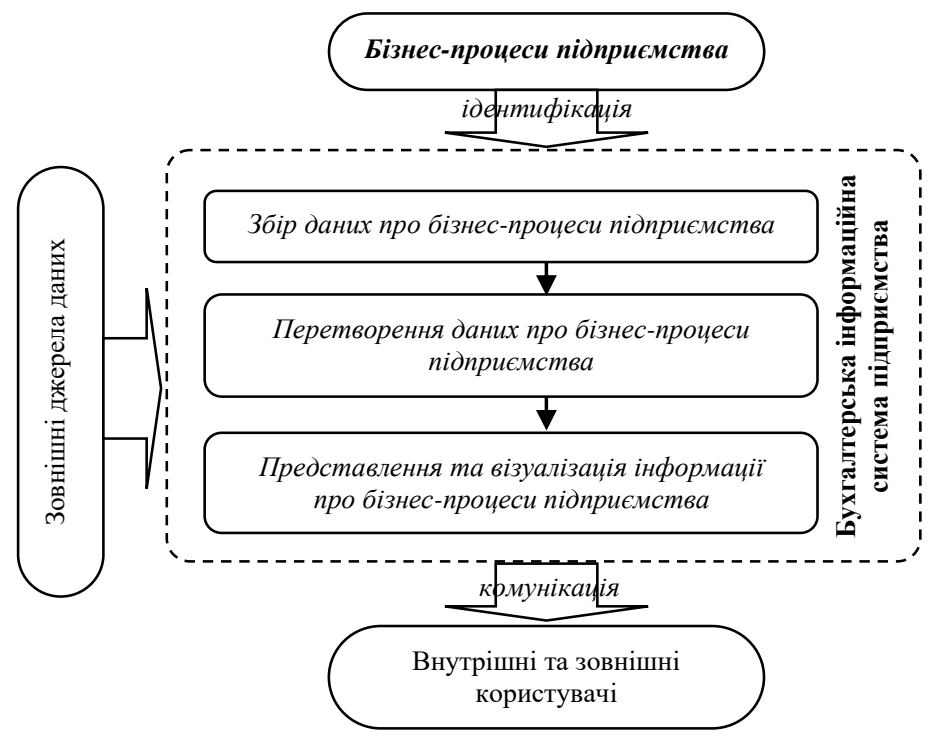

Рис. 2. Загальна модель функиіонування бухгалтерських інформаційних систем

3 огляду на рисунок 2 можна констатувати, що бухгалтерські інформаційні системи - це інформаційні системи, які здійснюють збір даних про бізнес-процеси підприємства та необхідні зовнішні дані, виконання процедур їх перетворення й обробки, забезпечуючи створення необхідної інформації для різних груп заінтересованих внутрішніх і зовнішніх користувачів та ії представлення в необхідному вигляді. На кожному 3 визначених трьох етапів в умовах сьогодення використовуються різні види інформаційних технологій, які забезпечують більш ефективну їх практичну реалізацію. Наприклад, для збору внутрішніх даних використовуються системи документообігу, для збору зовнішніх даних - бази даних, вебсторінки клієнтів, інших видів зовнішніх контрагентів. Для перетворення даних на облікову інформацію на основі використання бухгалтерської методології, що базується на системі подвійного запису, застосовується прикладне бухгалтерське програмне забезпечення, яке дозволяє забезпечити представлення кінцевої облікової інформації у вигляді фінансової, управлінської та податкової звітності. Як додаткові засоби представлення облікової інформації, іiі консолідації, передачі та обміну можуть використовуватися спеціалізовані вебресурси, сервіси та платформи, стандарти обміну діловою інформацією (XBRL) та електронні формати їі представлення (ESEF).

3 позиції бухгалтерських інформаційних систем облікові дані - це вхідні відомості, що надходять у вигляді первинних документів та інших засобів формалізації, а облікова інформація - оброблені відповідним чином облікові дані, які мають нове змістовне навантаження, і надаються користувачам у вигляді облікових регістрів та різних видів бухгалтерської звітності (фінансової, управлінської, статистичної, податкової тощо). 3 позиції інших інформаційних систем, зокрема з позиції системи інформаційної безпеки підприємства, бухгалтерські дані - це сукупність всіх наявних на підприємстві 
відомостей (даних та інформаціі) у вигляді документів, регістрів та бухгалтерської звітності, що зберігають на паперових носіях і в електронному вигляді (у вигляді електронних записів), і які можуть використовуватись різними суб'єктами для прийняття рішень. В цьому випадку бухгалтерські дані розуміються в їх широкому понятті - як об’єкт дослідження інших інформаційних систем, аніж бухгалтерської інформаційної системи.

Таким чином, бухгалтерські дані - це сукупність фінансової документації, проміжних облікових регістрів (записи на рахунках, узагальнюючі відомості, облікові регістри, головна книга) та бухгалтерської звітності, яка надається внутрішнім (менеджмент, вище керівництво) і зовнішнім користувачам для прийняття рішень (інвестори, позичальники) та здійснення контролю за іiі формуванням (аудитори, ревізори, податківці тощо), а також надається суб'єктам, які відповідають за ії збереження й безпечну передачу. Бухгалтерські дані можуть зберігатися та передаватись в паперовому вигляді, в електронному або в змішаному вигляді. Переважна більшість вітчизняних підприємств використовує змішану форму збереження та передачі бухгалтерських даних, оскільки повний перехід до комп'ютеризованого обліку потребує реінжинірингу всіх бізнес-процесів та вкладання значних фінансових ресурсів. Проте, враховуючи принцип економічної доцільності, перехід до тотальної комп'ютеризації бухгалтерського обліку в більшості випадків $є$ недоцільним, оскільки потребує комп'ютеризації діяльності не лише в частині бухгалтерської служби підприємства, а й в частині інших підрозділів, які є користувачами облікової інформації (управлінські підрозділи) та одночасно джерелом виникнення бухгалтерських даних (виробничі підрозділи).

Як і будь-яка інформаційна система, функціонування системи бухгалтерського обліку не залишається осторонь від проблем, з якими стикаються інші інформаційні системи, що забезпечують обробку інформації для прийняття управлінських рішень. Зокрема, в умовах сьогодення проблема порушень безпеки бухгалтерських даних $\epsilon$ надзвичайно актуальною $\mathrm{i}$ досягла критичного рівня, незважаючи на багаторічні спроби іiі вирішення як за допомогою техніко-технологічних, так i за допомогою різних видів організаційних заходів. Внаслідок цього необхідно сформувати теоретичні передумови для гарантування безпеки бухгалтерських даних, оскільки кількість порушень безпеки на сучасних підприємствах значно зростає. Зокрема, бухгалтерські служби підприємств та спеціалізовані бухгалтерські фірми найбільше схильні до виникнення загроз безпеки, ніж інші підрозділи підприємства, оскільки вони займаються обробкою цінної фінансової інформації, фінансових транзакцій та конфіденційних даних клієнтів, які можуть бути використані іншими суб'єктами для одержання конкурентних переваг. За даними представників компанії «Ace Cloud Hosting» [9] у 2020 році основними загрозами, на які потрібно звернути увагу представників бухгалтерських служб та фірм, $\epsilon$ такі: 1) використання застарілого програмного забезпечення; 2) порушення даних, спричинені діяльністю працівників; 3) недооцінка існуючих ризиків безпеки; 4) транзит даних; 5) віддалений доступ до даних; 6) криптоджекінг (видобуток криптовалют від імені хакерів шляхом несанкціонованого використання обчислювальних пристроїв); 7) встановлення слабких паролів.

Ця проблема значно актуалізується у зв'язку зі швидким поширенням та застосуванням сучасних технологічних інновацій у діяльності підприємств (мережевих, хмарних, інтелектуальної обробки даних тощо), особливо у великих та міжнародних компаніях, для ефективного управління якими необхідна швидко оброблена (в окремих випадках в режимі реального часу) та належним чином структурована i проаналізована облікова інформація. Тому впровадження нових інтернет-технологій 3 метою більш ефективного здійснення облікових процедур створює нові джерела порушення безпеки бухгалтерських даних на всіх етапах їх обробки, дозволяючи вже говорити про необхідність формування дієвої системи кібербезпеки бухгалтерських даних як нового об’єкта системи ризик-менеджменту підприємства. Наприклад, бухгалтерські інформаційні системи, що функціонують в мережевому середовищі, мають свої специфічні проблеми безпеки бухгалтерських даних. На думку Й.Женга [11, с. 419-420] функціонування таких систем супроводжується виникненням загроз безпеки на трьох рівнях: 1) на технічному рівні (загрози несанкціонованого доступу до даних під час їх введення та збереження в архівованому вигляді); 2) на рівні внутрішнього контролю функціонування облікової системи (ретроспективного та превентивного); 3) на рівні облікового персоналу (загрози здійснення неумисних помилок, недостовірних припущень та неефективного виконання облікових процедур).

В цілому під безпекою даних розуміється процес їх захисту від несанкціонованого доступу різних осіб та пошкодження даних протягом всього циклу їх використання на підприємстві, тобто від моменту їх виникнення (одержання) до моменту їх знищення (забуття). Разом із забезпеченням безперебійної роботи обладнання, захист даних $\epsilon$ складовою забезпечення інформаційної безпеки підприємства. В умовах формування мережевого інформаційного суспільства, яке характеризується тим, що на підприємствах переважно відбувається зберігання та обробка електронної інформації за допомогою комп'ютерної техніки, а іiі передача здійснюється за допомогою мереж (Інтернет, корпоративних, локальних), виникає набагато більша кількість загроз безпеці бухгалтерських даних, ніж це було за умов використання ручної форми їх обробки та формування облікової інформації для прийняття рішень. 
Думки дослідників стосовно того, які принципи мають бути покладені в основу розробки системи безпеки в процесі реалізації облікових процедур на підприємствах, різняться між собою. Так на думку представників Американського інституту СРА (АІСРА) та Канадського інституту привілейованих бухгалтерів (CICA), безпеку бухгалтерських даних можна досягти шляхом дотримання принципів, які забезпечують їх надійність. До таких принципів належать: безпека - доступ до системи та ії даних контролюється і обмежується лише авторизованими користувачами); конфіденційність - захист конфіденційної інформації від несанкціонованого розголошення; приватність - збір, використання та розкриття особистої інформації про клієнтів здійснюється лише у встановленому порядку; цілісність обробки - точна, повна та своєчасна обробка даних, виконана згідно із встановленими дозволами; доступність - система доступна для виконання оперативних доручень та контрактних обов'язків [10]. Наведений вище підхід до виокремлення принципів безпеки даних не співпадає з позицією дослідників, які займаються загальними проблемами побудови системи інформаційної безпеки на підприємствах. Сьогодні в основу системи інформаційної безпеки підприємства значною кількістю вчених (Дж.Андресс [5, с. 4-5], М.Бішоп [6, с. 4-6], Р.Дж. Бойл та Р.Р. Панко [7, с. 3], В.I. Глухих [1, с. 6]) покладаються принципи, що формують тріаду інформаційної безпеки:

1. Цілісність даних - захист від збоїв, що призводять до втрати інформації, а також захист від неавторизованого створення або знищення даних;

2. Конфіденційність даних;

3. Доступність даних для всіх авторизованих користувачів.

Цілісність бухгалтерських даних - це можливість заважати заінтересованим суб'єктам несанкціонованим або небажаним способом змінювати дані. Для того, щоб зберегти цілісність бухгалтерських даних, необхідно не тільки мати спеціалізовані програмні та технічні засоби для запобігання несанкціонованим змінам, але також має існувати можливість скасовувати небажані санкціоновані зміни. Зокрема, залежно від посадових обов'язків, прописаних в Наказі про організацію облікової служби на підприємстві, в бухгалтерських інформаційних системах для різних користувачів та адміністраторів з метою запобігання несанкціонованим змінам проводиться авторизація, встановлюються обмеження стосовно можливості внесення змін (виправлень, видалень) в різних довідниках та елементах системи (первинних документах, в господарських операціях, в проміжних облікових регістрах, звітності тощо). Внаслідок таких обмежень несанкціонований користувач, тобто у якого відсутні права на здійснення таких дій, не може виконувати їх над цим елементом бухгалтерської інформаційної системи. Наприклад, в програмних продуктах компанії «BAS ERP» в журналі введення господарських операцій для того, щоб видалити господарську операцію, суб'єкт, який іï ввів, спочатку лише помічає іï на видалення, а сама господарська операція видаляється лише після застосування відповідної опції суб'єктом, який має на це права. Таким чином, бухгалтерські інформаційні системи мають бути обладнані для належної реакції на будь-який із цих сценаріїв, щоб забезпечити захист цілісності бухгалтерських даних.

Окрім цього, в бухгалтерських інформаційних системах, які $є$ складовими великих управлінських інформаційних систем (BPM, ERP тощо), існує можливість скасовувати або відміняти небажані зміни, що встановлюється на рівні адміністратора системи, а також використовується значна кількість інших методів забезпечення цілісності даних, найпопулярнішими серед яких є перевірка помилок, перевірка процедур (validation procedures) та резервне копіювання.

Цілісність бухгалтерських даних може бути порушена внутрішніми й зовнішніми вторгненнями, пошкодженим обладнанням бухгалтерських інформаційних систем, використанням шкідливого програмного забезпечення та вірусами, помилками суб'єктів ведення бухгалтерського обліку та при узагальненні і консолідації даних (бухгалтерським менеджментом), помилками оновлення або помилками, які виникають під час передачі чи копіювання бухгалтерських даних з одного джерела в інше.

3 метою забезпечення цілісності бухгалтерських даних на підприємстві, працівники бухгалтерської служби та розробники бухгалтерської інформаційної системи зобов'язані дотримуватися такої системи правил, яка формує розумну впевненість у тому, що здійснювані працівниками дії в межах їх посадових обов’язків відповідають вимогам керівництва та в цілому спрямовані на забезпечення інформаційної безпеки підприємства:

- формування і використання адекватної системи контролю бухгалтерських даних, що включає незалежні засоби стримування та противаги;

- усі працівники бухгалтерської служби несуть відповідальність за забезпечення належного контролю даних. Якщо вони цього не роблять, то всі працівники мають брати активну роль у розробці та здійсненні необхідних коригувальних дій у випадку порушення їх цілісності;

- кожен працівник бухгалтерської служби при введенні господарських операцій на основі первинних документів має забезпечити відповідність зареєстрованих проведень фактично існуючим об'єктам обліку. Повинен існувати механізм виявлення розбіжностей між введеними проведеннями і первинними документами, та мають бути створені необхідні умови для здійснення коригувальних дій за такої необхідності; 
- кожен працівник бухгалтерської служби зобов'язаний забезпечити достовірність введення господарських операцій в систему. Достовірність означає: відображення фактичних значень; деталізація, належна ідентифікація та класифікація; своєчасність введення в необхідному звітному періоді; надійність збереження; безперешкодна доступність для запиту або для формування звітності; захищеність від неналежних змін;

- бухгалтерські та інші інформаційні системи підприємства, що використовуються для формування бухгалтерської звітності, мають бути захищеними, надійними та доступними. Вони повинні будуватися на основі обгрунтованих моделей обробки даних та використовувати технологію, яка дозволяє належним чином проводити обмін бухгалтерськими даними між різними підрозділами підприємства та різними групами стейкхолдерів;

- бухгалтерські та інші інформаційні системи підприємства, що використовуються для формування бухгалтерської звітності (фінансової, нефінансової, інтегрованої, управлінської, податкової), повинні відповідати потребам користувачів облікової інформації. Їх інтерфейси мають містити засоби контролю, що забезпечуватимуть синхронізацію та взаємоузгодження бухгалтерських даних у різних підсистемах;

- усі мережі, в тому числі електронна пошта, через які менеджмент підприємства, вище керівництво або зовнішні стейкхолдери одержують доступ до бухгалтерських даних, мають бути надійними, стабільними та безпечними.

Конфіденційність бухгалтерських даних характеризує здатність підприємства захищати бухгалтерські дані від тих суб'єктів, що не мають повноважень на їх перегляд. Конфіденційність у бухгалтерських інформаційних системах реалізується на різних рівнях їх функціонування завдяки розмежуванню прав доступу між суб'єктами, які займаються введенням, обробкою, узагальненням бухгалтерських даних, а також конфігуруванням і адмініструванням таких систем. Наприклад, особлива увага на підприємствах має приділятися даним, що стосуються заробітної плати працівників підприємства, його керівництва, виплат премій та бонусних винагород, оскільки оприлюднення такої інформації може стати причиною порушення робочого мікроклімату та негативно впливатиме на загальні результати функціонування підприємства. Для забезпечення конфіденційності інформації, до роботи 3 довідниками інформаційної системи, в яких зберігається інформація про різні види грошової винагороди працівників підприємства, мають допускатися лише чітко визначені працівники бухгалтерської служби, 3 якими укладається договір про нерозголошення цієї інформації як комерційної таємниці.

Також, враховуючи існування сигнальної функції бухгалтерського обліку, важливу роль з позиції конкурентної боротьби відіграє фінансова інформація про результати функціонування підприємства за звітний період. Зокрема, від рівня прибутковості залежить рівень виплачуваних дивідендів та ринкова вартість акцій підприємства. Тому у випадку дострокового оприлюднення такої інформації через інсайдерів, тобто несанкціонованих користувачів системи, інші учасники ринку капіталу можуть використати іï для здійснення інвестиційних вкладень (або для продажу збиткових цінних паперів), що в цілому внаслідок виникнення подібної інформаційної асиметрії призводитиме до звуження ринку через те, що інші учасники ринку будуть залишати його (за Дж.Акерлофом). У випадку настання подібної ситуації таке підприємство також втратить свою репутацію добросовісного учасника ринку капіталу, що негативно вплине на його ринкову вартість. Тому для уникнення подібних випадків порушення конфіденційності інформації процес формування фінансових результатів підприємства і складання проформ фінансової звітності в багатьох бухгалтерських інформаційних системах здійснюється в спеціалізованому режимі, до якого має доступ лише адміністратор системи (головний бухгалтер, фінансовий директор тощо). Окрім цього, з позиції репутаційних ризиків для підприємства і його власників важливою $є$ інформація про сплачені підприємством податки. Розкриття такої інформації може стати причиною втрати довіри до підприємства як щодо інших учасників ринку (інвесторів, позичальників), так і до власника підприємства як до окремої фізичної особи.

Конфіденційність може бути порушена як через необачливі дії користувачів бухгалтерських інформаційних систем, наприклад, у випадку втрати засобів доступу до неї (флешки з базою даних, ноутбука, телефона тощо), так і через умисні дії осіб, заінтересованих у порушенні конфіденційності (проникнення в інформаційну систему зловмисником, перехоплення бухгалтерських даних під час їх транзиту або передачі, підглядування в монітор співробітника тощо).

Доступність бухгалтерських даних - це можливість отримати доступ до них у той момент, коли це $\epsilon$ необхідно всім заінтересованим користувачам (операторам, адміністраторам, менеджменту підприємства тощо). Доступність до бухгалтерських даних також означає забезпечення безперервної роботи бухгалтерської інформаційної системи, усіх пї компонентів та забезпечення постійної здатності взаємодіяти з обліковою інформацією. Це означає, що робота зазначених далі елементів бухгалтерської інформаційної системи має бути правильною i безперервною: комп'ютерних систем, що використовуються для зберігання та обробки облікової інформації; засобів безпеки, що використовуються для захисту бухгалтерської інформаційної системи; каналів зв'язку, що використовуються для передачі облікової інформації користувачам; високосекретних систем, що 
забезпечують безперервність захисту в будь-який час; засобів запобігання будь-яким перебоям в обслуговуванні внаслідок відключення електроенергії або відмови обладнання, оновлення бухгалтерської інформаційної системи чи її модернізації.

Втрата доступу до бухгалтерських даних може бути зумовлена впливом внутрішніх та зовнішніх факторів. Наприклад, доступ до бухгалтерських даних може бути втрачений через обрив постачання електроенергії, проблеми з операційною системою чи додатками, мережеві атаки або через неполадки, які можуть виникати в системі. Коли зовнішні сторони, такі як зловмисники, є причиною цих проблем, подібні втручання називаються атакою відмови в обслуговуванні (DoS). Наприклад, на початку 2019 року всесвітньо відома нідерландська компанія «Wolters Kluwer», що розробляє програмне забезпечення для бухгалтерського обліку податкових розрахунків, стала жертвою DoS-атаки, внаслідок якої значна кількість користувачів облікового програмного забезпечення даного розробника по всьому світу не могла працювати протягом декількох днів. Користувачами цього програмного забезпечення $\epsilon$ 100 бухгалтерських фірм-лідерів США, 90 \% провідних банків світу та 93 \% компаній, що належать до рейтингу «Fortune 500» [8]. В результаті такої атаки працівники цих підприємств та організацій не могли мати доступ до персональних даних клієнтів, своєчасно заповнювати податкові декларації і забезпечити формування фінансової звітності, що зберігається на хмарних серверах. Існування такої ситуації призвело до виникнення панічних настроїв серед професійних облікових кіл США, оскільки окремим компаніям довелося формувати бухгалтерську звітність уручну, що в цілому наклало негативний відбиток на перспективи застосування хмарних технологій для організації та ведення бухгалтерського обліку.

В цілому формування системи безпеки бухгалтерських даних визначає рівень надійності облікової системи та рівень якості вихідної облікової інформації, що генерується бухгалтерською інформаційною системою підприємства (рис. 3).

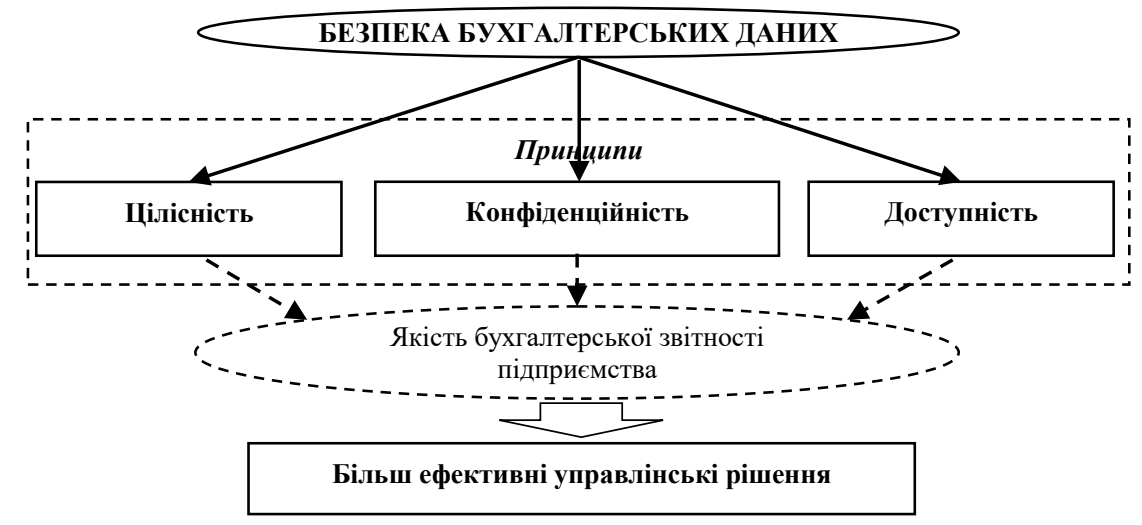

Рис. 3. Роль принцчипів безпеки даних у підвищенні якості облікової інформації

Дотримання трьох розглянутих вище принципів захисту даних у бухгалтерських інформаційних системах (рис. 3) забезпечує належний якісний рівень облікової інформації, яка використовується для прийняття рішень, створюючи таким чином необхідні передумови для забезпечення ефективності функціонування управлінських систем. Для успішного впровадження наведених вище принципів безпеки бухгалтерських даних у діяльність конкретного підприємства необхідно:

1. Визначити коло користувачів бухгалтерських інформаційних систем i адміністраторів, необхідних для захисту комп'ютерних систем, мереж, облікових даних та інформації у всіх їх формах та на різних стадіях їх збору, обробки й представлення, а також у випадках їх передачі через мережі та надання користувачам за запитом;

2. Визначити та скоригувати механізми, за допомогою яких досягається виконання конкретних посадових обов'язків кожним працівником бухгалтерської служби, залученим до роботи 3 бухгалтерською інформаційною системою, визначити рівень його відповідальності при виникненні ризиків втрати безпеки бухгалтерських даних;

3. Визначити процедури, які сприятимуть мінімізації або уникненню загроз та ризиків втрати безпеки бухгалтерських даних, а також способів боротьби з ними при їх настанні.

Висновки та перспективи подальших досліджень. Розвиток інформаційного суспільства та активна діджиталізація діяльності підприємств має прямий вплив на систему бухгалтерського обліку. Формування інфраструктури нового типу для обробки облікових даних, що базується на застосуванні технологічних інновацій (Artificial Intelligence, Cloud Computing, Internet of Things тощо) та інтернеттехнологій, трансформує традиційні облікові процедури і робить ще більш залежною облікову систему від належної безпеки бухгалтерських даних. 
3 позиції системи інформаційної безпеки підприємства бухгалтерські дані є сукупністю фінансової документації, проміжних облікових регістрів і бухгалтерської звітності, яка надається внутрішнім та зовнішнім користувачам для прийняття рішень і здійснення контролю за ії формуванням, а також суб'єктам, які відповідають за іiі збереження й безпечну передачу. Безпека бухгалтерських даних полягає y їх захисті від несанкціонованого доступу різних осіб та пошкодження протягом всього циклу їх використання на підприємстві від моменту виникнення до моменту знищення. Для формування дієвої системи безпеки бухгалтерських даних обгрунтовано необхідність ії побудови на основі принципів цілісності, конфіденційності та доступності, що в цілому сприятиме підвищенню якісного рівня бухгалтерської звітності підприємства.

Перспективою подальших досліджень $є$ аналіз впливу впровадження окремих технологічних інновацій на розвиток бухгалтерського обліку, наприклад, Artificial Intelligence, та аналіз можливості виникнення нових загроз бухгалтерським даним в таких нових умовах функціонування облікової системи підприємства і пошук шляхів для їх мінімізації й усунення.

\section{Список використаної літератури:}

1. Глухих В.И. Информационная безопасность и защита данных : учебное пособие / В.И. Глухих. - Иркутск : Изд-во ИГТУ, 2011. - 250 с.

2. Годовой отчет Cisco по информационной безопасности за 2018 год. Краткий обзор. - Сан-Хосе : Корпорация Cisco, 2018. - 68 c.

3. Легенчук С.Ф. Майбутнє корпоративної звітності: історія, перспективи та проблеми / С.Ф. Легенчук // Облік і фінанси. - 2020. - № 2 (88). - С. 29-38.

4. Легенчук С.Ф. Документування в бухгалтерському обліку: процесний підхід : монографія / С.Ф. Легенчук, К.О. Вольська, О.В. Вакун. - Івано-Франківськ : Видавець Кушнір Г.М., 2016. - 228 с.

5. Andress J. Foundations of information security. A Straightforward Introduction / J.Andress. - San Francisco: No Starch Press, 2019. - 222 p.

6. Bishop M. Computer Security. Art and Science / M.Bishop. - 2nd ed. ; with contributions from E.Sullivan and M.Ruppel. - Pearson Education, Inc, 2019. - 1384 p.

7. Boyle R.J. Corporate Computer Security / R.J. Boyle, R.R. Panko. - Pearson, 2013. - 664 p.

8. Fazzini $K$. A malware attack against accounting software giant Wolters Kluwer is causing a 'quiet panic' at accounting firms / K.Fazzini [Electronic resource]. - Access mode : https://www.cnbc.com/2019/05/08/wolterskluwer-accounting-giant-hit-by-malware-causing-quiet-panic.html.

9. Kadian N. Top 7 Security Threats Accounting Firms Should Watch in 2020 / N.Kadian [Electronic resource]. Access mode : https://www.acecloudhosting.com/blog/security-threats-accounting-firms/.

10. What are Accounting Information Systems? [Electronic resource]. - Access mode : https://www.accountingedu.org/accounting-information-systems/.

11. Zhang Y. Security Risk of Network Accounting Information System and Its Precaution / Y.Zhang // Advances in Computer Science Research : 3rd International Conference on Mechatronics Engineering and Information Technology (ICMEIT 2019). - 2019. - Vol. 87. - P. 418-422.

\section{References:}

1. Glukhikh, V.I. (2011), Informatsionnaya bezopasnost' $i$ zashchita dannykh, uchebnoe posobie, Izd-vo IGTU, Irkutsk, $250 \mathrm{p}$.

2. Godovoi otchet Cisco po informatsionnoi bezopasnosti za 2018 god. Kratkii obzor (2018), Korporatsiya Cisco, San-Khose, 68 p.

3. Legenchuk, S.F. (2020), «Majbutnje korporatyvnoi' zvitnosti: istorija, perspektyvy ta problemy», Oblik $i$ finansy, No. 2 (88), pp. 29-38.

4. Legenchuk, S.F., Vol's'ka, K.O. and Vakun, O.V. (2016), Dokumentuvannja v buhgalters'komu obliku: procesnyj pidhid, monografija, Vydavec' Kushnir G.M., Ivano-Frankivs'k, 228 p.

5. Andress, J. (2019), Foundations of information security. A Straightforward Introduction, No Starch Press, San Francisco, 222 p.

6. Bishop, M. (2019), Computer Security. Art and Science, 2nd ed., with contributions from Sullivan, E. and Ruppel, M., Pearson Education, Inc, 1384 p.

7. Boyle, R.J. and Panko, R.R. (2013), Corporate Computer Security, Pearson, 664 p,

8. Fazzini, K. (2019), «A malware attack against accounting software giant Wolters Kluwer is causing a 'quiet panic' at accounting firms», [Online], available at: https://www.cnbc.com/2019/05/08/wolters-kluwer-accounting-gianthit-by-malware-causing-quiet-panic.html

9. Kadian, N. (2020), «Top 7 Security Threats Accounting Firms Should Watch in 2020», [Online], available at: https://www.acecloudhosting.com/blog/security-threats-accounting-firms/

10. «What are Accounting Information Systems?» (2021), [Online], available at: https://www.accountingedu.org/accounting-information-systems/

11. Zhang, Y. (2019), «Security Risk of Network Accounting Information System and Its Precaution», Advances in Computer Science Research, 3rd International Conference on Mechatronics Engineering and Information Technology (ICMEIT 2019), Vol. 87, pp. 418-422. 
Легенчук Сергій Федорович - доктор економічних наук, професор, завідувач кафедри інформаційних систем в управлінні та обліку Державного університету «Житомирська політехніка».

http://orcid.org/0000-0002-3975-1210.

Наукові інтереси:

- теорія та історія бухгалтерського обліку;

- облік нематеріальних активів;

- діджиталізація системи обліку.

Царук Ірина Михайлівна - кандидат економічних наук, доцент, доцент кафедри менеджменту і підприємництва Державного університету «Житомирська політехніка».

https://orcid.org/0000-0002-9628-3257.

Наукові інтереси:

- психологічні аспекти розвитку маркетингу;

- конфліктологія.

Назаренко Тетяна Петрівна - кандидат економічних наук, доцент, доцент кафедри інформаційних систем в управлінні та обліку Державного університету «Житомирська політехніка».

http://orcid.org//0000-0001-7702-8122.

Наукові інтереси:

- теорія аудиту та внутрішньогосподарського контролю;

- бухгалтерська експертиза.

Стаття надійшла до редакції 16.04.2021. 